\title{
The Law Enforcement in Implementation of Diversion on Children in Confrontation with the Law
}

\section{Nur Khasanah*) and Umar Ma'ruf**)}

*) Student of Master of Law, Faculty of Law, Universitas Islam Sultan Agung (UNISSULA) and Members of the Indonesian National Police, email: nur.girly91@gmail.com

**) Faculty of Law Universitas Islam Sultan Agung

\begin{abstract}
.
This study aims to analyze law enforcement in the application of diversion to children in conflict with the law. Constraints faced in applying diversion to children who are faced with the law and its solutions. This study uses a sociological juridical approach, with descriptive analytical research specifications. The data used in this study are secondary data obtained through library research and primary data which are then analyzed qualitatively using law enforcement theory and restorative justice theory. The result of this research is the action of transferring the settlement of juvenile cases from the criminal justice process to the noncriminal justice process. This diversion really needs child-specific handling that aims to provide the best interests of the child supported by adequate police human resources and the availability of legal assistance, community counselors, professional social workers and family / guardian and community support. Constraints faced a) Unifying Thoughts between Victims and Children in Conflict with the Law in order to Achieve an Agreement, b) Inadequate facilities and facilities, c) Community understanding of diversion is still lacking, d) Understanding of the community and other law enforcement officials on Diversion still lacking, $e$ ) The role of the community is still minimal, especially from the community who are victims, $f$ ) Cooperation with other agencies related to the implementation of Diversion has not been going well. Solutions to overcome these obstacles are a) Conducting separate meetings (caucuses) to unify ideas between victims and children in conflict with the law so that an agreement is reached, b) Optimizing facilities and infrastructure, c) Establishing Intensive Communication with Other Law Enforcement Officials. , d) Conducting Diversion Socialization among the Community, e) Making an Agreement on Supervision of the Implementation of the Diversion Agreement Results.

Keywords: Law Enforcement; Implementation; Diversion; Children.
\end{abstract}

\section{Introduction}

In accordance with the explanation of Article 1 paragraph (3) of the 1945 Constitution of the Constitution of the Republic of Indonesia (UUD 1945), it is clear that "Indonesia is a State of Law". If the provisions are interpreted grammatically, then there will be a consequence of a rule of law, namely that all forms of decisions, acts of state equipment, all attitudes, behaviors and actions including those taken by citizens, must have a legal basis or in other words all must have legal legitimacy. ${ }^{1}$

In the life of the nation and state, security is a determining factor in the life of the nation and the state of implementing a sovereign and authoritative government, which is the main condition that supports the realization of a just,

${ }^{1}$ Aristo, Muhammad Adiel. \& Ma'ruf, Umar. "Criminal Law Policy against Actor of Criminal Performance Persecution". In Jurnal Daulat Hukum Volume 3 Issue 1, March 2020 ISSN: 2614-560X 
prosperous, prosperous and civilized life in a civil society system based on Pancasila and the Constitution of the Republic of Indonesia. 1945 Indonesia. Domestically, the National Police carries out law enforcement efforts through the process of investigating and investigating criminal acts as regulated in Act Number 2 of 2002 concerning the Indonesian National Police. ${ }^{2}$

Children are an inseparable part of the sustainability of human life and the sustainability of a nation and state. In the Indonesian constitution, children have a strategic role which explicitly states that the state guarantees the right of every child to live, grow and develop as well as protection from violence and discrimination. Therefore, the best interests of children should be lived out as the best interests for the survival of mankind. The consequences of the provisions of Article 28B of the 1945 Constitution of the Republic of Indonesia need to be followed up by making government policies aimed at protecting children. ${ }^{3}$

Behavior deviations committed by children are more precisely called child delinquency. Child delinquency which is taken from the term juvenile delinquency, which juvenile means young, children, youth, characteristics of youth, cash in youth, characteristics of adolescence; while delinquency means wrong doing, neglected / ignored, which is then expanded to mean being evil, social, criminal, rule breaker, noisy maker, troublemaker, terrorist, irreparable, ungodly, and others. ${ }^{4}$

There has been a growing thought in the global or international community and international advocacy movements that the fulfillment of children's rights is a serious problem for every country. In particular, protection of children when they are related to a criminal act in the position of a suspect or defendant. ${ }^{5}$ This is due to the development of a paradigm in the philosophy of juvenile justice, which initially was retributive justice, then changed to rehabilitation, then the latter became restorative justice. ${ }^{6}$ The juvenile justice system should be aimed at the welfare of children and avoiding the bad stigmatization of children in conflict with the law, as confirmed in United Nations (UN) regulations, in the United Nations Standard Minimum Rules for the Administration to the Administrations of Juvenile Justice (SMRJJ) or The Beijing Rules, that the objectives of juvenile justice (Aims of Juvenile Justice), as follows. ${ }^{7}$ The juvenile justice system shall emphasize well being of the juvenile and shall always be in proportions to the circumstance of both the offenders and offence ${ }^{8}$

\footnotetext{
${ }^{2}$ Srinitri, Ni Made., \& Ma'ruf, Umar. "Progressivity Of Criminal Handling Fraud And Disease By The Directorate Of The General Criminal Researcher Of Central Java Regional Police (POLDA)". in Jurnal Daulat Hukum Volume 3 Issue 1, March 2020 ISSN: 2614-560X

${ }^{3}$ General explanation of the SPPA Law

${ }^{4}$ Nashriana. (2011). Perlindungan Hukum Pidana Bagi Anak Di Indonesia, Jakarta: Raja Grafindo Persada, p. 25.

${ }^{5}$ Anggara., Napitulu, Ersmus A.T., \& Hernowo, Alex Argo. (2016). Studi Implementasi Penanganan Anak di Pengadilan Berdasarkan UU SPPA, Jakarta, p. 1

${ }^{6}$ Priyadi, Socialization \& Roadmap for the Implementation of Law no. 11/2012, retrieved from http://jabar.kemenkumham.go.id/ accessed on 2 May 2020 at 11.24 WIB

${ }^{7}$ Wahyudi, Setya. (2011) Implementasi Ide Diversi dalam Pembaruan Sistem Peradilan Pidana Anak di Indonesia, Yogayakarta: Genta Publishing, p. 2.

${ }^{8}$ United Nations Standard Minimum Rules for the Administration to the Administrations of Juvenile Justice ("The Beijing Rules"). Adopted by General Assembly Resolution 40/33 of 29 November 1985,
} 
The juvenile justice system is required to put the best interests of children in conflict with the law and always pay attention to the situation of the two children, both as perpetrators and as victims. Children in Conflict with the Law $(\mathrm{ABH})$ include children who are in conflict with the law, children who are victims of crime, and children who are witnesses of crime.

General description of the condition of the development policy for women's empowerment and child protection in the era of regional autonomy is part of improving the quality of human resources, including achieving gender equality and justice. This is in accordance with the national commitment by signing several international conventions that provide a strong basis for improving the quality of women and child protection, through the ratification of the United Nations Convention for the Eliminations and Determination Against Women (CEDAW) with Act No. 4 of 1987, signed the results of the International Convention on Women in Beijing, signed Convention No. 100 of the International Labor Organization (ILO) which implies equal payment for equal work.

Based on the background of the problems mentioned above, this study aims to analyze law enforcement in the application of diversion against children who are faced with the law, as well as its obstacles and solutions.

\section{Methods}

The approach used is the sociological juridical legal research method, namely research carried out by examining how a rule is implemented in the field, especially with regard to law enforcement in the application of diversion against children who face the law at the Pati Police. This research is descriptive-analytical, namely research that describes or describes the object of research which is then analyzed through qualitative juridical analysis. ${ }^{9}$ The data used in this study are secondary data obtained through library research and primary data which are then analyzed qualitatively using law enforcement theory and restorative justice theory. The method used is the qualitative analysis method, a conclusion can be drawn to be analyzed juridical-qualitatively, namely grouping the data according to the aspects studied without using numbers or in other words the data appears in the form of words, with the starting point in law or applicable legal norms. ${ }^{10}$

\section{Results and Discussion}

\subsection{Law Enforcement in the Application of Diversion to Children in Confrontation with the Law}

Law enforcement is a process that can guarantee legal certainty, order and protection of the law by maintaining harmony, balance and harmony between civilian morality which is based on actual values in a civilized society. Law

\footnotetext{
Human Right A Compilation of International Instrumens Volume I (First Part) Universal instrumens, United Nations, New York, 1993.

${ }^{9}$ Sunggono, Bambang. (1996). Metode Penelitian Hukum, Jakarta: Rajawali Pers, p. 42

10 Matthew , B. Miles., and Huberman, A. Michael. (1992). Analisa Data Kualitatif. Jakarta: UI Press. p. 15-16
} 
enforcement as an activity process that includes various parties including the community in the framework of achieving goals, is a must to see criminal law enforcement as a criminal justice system. ${ }^{11}$

The judicial process against children often loses its essential meaning, namely as a mechanism that must end in an effort to protect the best interest of the child. Juvenile justice is often a process that is only oriented towards formal law enforcement and is not oriented towards the interests of the child.

Compiled from data from the Social Service for Women's Empowerment for Child Protection and Family Planning in Pati Regency in 2019, the number of children dealing with the law was 4 cases, then in 2020 January-June increased to 5 cases.

One of the cases of children who are in conflict with the law is Moh Adib Ulinnuha (15 years) who is threatened with five years in prison. Moh Adib Ulinnuha is a suspect in the theft of 1 (one) Honda Vario unit.

Based on the results of interviews with Bripka Siswarto, convey:12 "For children who are in conflict with the law or children who are suspected of committing criminal acts, seen from the number of cases reported at the Pati Police, not all cases of children have been transferred or continued to the prosecutor's level during the investigation process, sometimes also from the perpetrators and the complainants who have made peace efforts".

Usually peace by means of Restorative Justice occurs because of the assistance of third parties such as religious or community leaders. The reconciliation is usually accompanied by compensation which is marked with a Diversion agreement between the victim and the perpetrator by involving the Community Advisor from the Bapas. ${ }^{13}$

Law Enforcement in the Application of Diversion to Children Confrontation with the Law is the act of transferring the settlement of children's cases from criminal justice processes to processes outside of criminal justice. This diversion really needs child-specific handling that aims to provide the best interests of the child supported by adequate police human resources as well as the availability of legal assistance, community advisers, professional social workers and family / guardian and community support.

\subsection{Constraints Faced in Applying Diversion to Children Who Are Faced with the Law and Its Solutions}

The process of handling criminal acts committed by children is known as diversion. Diversion is a process of transferring children's cases from criminal justice processes to non-criminal justice processes, which means that there is a process of deliberation in handling cases of children in conflict with the law.

The great desire to always punish criminals with imprisonment not only makes prison full, but also hinders them the application of restorative justice. Even

\footnotetext{
11 Arief, Badra Nawawi. (2001). Masalah Penegakan Hukum dan Kebijakan Penanggulangan Kejahatan, Bandung: Citra Aditya Bakti. p. 23

12 Results of interviews with Bripka Siswarto, on July 22, 2020, at 10.45 WIB

${ }^{13}$ Results of interviews with Briptu Ayu Puji Lestari,on July 22, 2020, at 13.05 WIB
} 
if the perpetrators of the crime are children, the punitive culture that thrives in society will hinder the application of diversion.

There is an assumption in the juvenile criminal justice system with a restorative paradigm, that in achieving the goal of imposing sanctions, the victim should have the right to be actively involved in the judicial process. indicators of achieving the goal of imposing sanctions are achieved by looking at whether the victim has been restored, the victim's satisfaction, the amount of compensation, the perpetrator's awareness of his actions, the number of repair agreements made, the quality of work services and the overall process that occurs. The forms of sanctions are restitution, victim-perpetrator mediation, victim service, community restoration, direct service to victims or restorative fines. ${ }^{14}$

Restorative justice as any action to uphold justice by repairing the damage caused by a criminal act. Restorative justice is based on the type of punishment in the form of community service, compensation, and other forms apart from imprisonment, by allowing the convict to remain active in society. ${ }^{15}$

Children who are faced with the law are based on Act Number 11 of 2012 concerning the Criminal Justice System for Children, and diversion can be carried out if the case meets the requirements for diversion. In Act Number 11 of 2012 Article 7 paragraph 2 states that the conditions for a child case can be diversified if the case is: "Punishable by imprisonment of less than 7 (seven) years and does not constitute a repeat offense"

With the report from the victim, then investigators at the Women and Child Protection Unit Sat Reskrim at the Pati Police carried out an investigation and investigation as well as an examination and the investigator wrote a letter asking for advice to the social adviser and the results of the research from the community advisor must be submitted to the investigator at the Women's Protection Unit and Son of the Criminal Investigation Unit of the Pati Police. If the perpetrator is a minor, the investigator will examine the conditions under which the diversion attempt can be made. If these conditions are met, the investigators at the Women and Children Protection Unit will summon the families of the victims, the families of the perpetrators, community counselors, community leaders, social agencies and agencies related to child problems to carry out the diversion process.

As stated by the PPA Sat assistant investigator, that: "The success or failure of the implementation of the investigator diversion usually sees the threat of punishment or cases committed by the perpetrator if the offense is light or the threat of punishment is under 7 (seven) years, such as cases of light maltreatment or ordinary theft. There is a big possibility that diversion can be made through the concept of Restorative Justice. However, for certain cases, such as rape and serious maltreatment, these cases are usually transferred or continued to the prosecutor's office. However, seeing that the perpetrators are still children, they must still pay attention to children's rights during the investigation. ${ }^{16}$

\footnotetext{
14Djamil MN. (2013) Anak Bukan untuk Dihukum, Sinar Grafika (cetakan kedua), p. 46-47

${ }^{15}$ Kaligis, OC. (2006). Pelindungan Hukum Atas Hak Asasi Tersangka, Terdakwa, dan Terpidana, Jakarta: Alumni, p. 125

16 Results of interviews with Aiptu Saeful Hidayat,, on July 22, 2020, at 14.05 WIB
} 
Based on the results of interviews with Aiptu Saeful Hidayat, concerning the obstacles faced in applying diversion to children in conflict with the law, namely:

a. Unifying the thoughts of the victim and the child in conflict with the law in order to reach an agreement

b. Inadequate facilities and facilities

c. Public understanding of diversion is still lacking

d. Public understanding and other law enforcement officials on Diversion are still lacking.

e. The role of the community is still minimal, especially from the community who are victims.

f. Cooperation with other agencies related to the implementation of Diversion has not been going well.

Solutions to overcome the obstacles faced in applying diversion to children in conflict with the law are:

a. Conduct separate meetings (caucuses) to unify ideas between the victim and the child in conflict with the law so that an agreement is reached

b. Optimizing facilities and infrastructure

c. Establishing Intensive Communication with Other Law Enforcement Officials

d. Organizing Socialization about Diversion Among the Community

e. Make an Agreement on Supervision of the Implementation of the Diversion Agreement Results

\section{Closing}

\subsection{Conclusion}

Based on the previous description, the writer can conclude that:

a. Law Enforcement in the Application of Diversion to Children Confrontation with the Law at the Pati Resort Police is an act of transferring the settlement of juvenile cases from the criminal justice process to processes outside the criminal court. This diversion really needs a special handling of children which aims to provide the best interests of children supported by adequate police human resources and the availability of legal assistance, community counselors, professional social workers and family / guardian and community support.

b. Constraints faced in the application of diversion against children who are in conflict with the Pati Police and its solutions

Obstacles:

- Unifying the thoughts of the victim and the child in conflict with the law in order to reach an agreement

- Inadequate facilities and facilities

- Public understanding of diversion is still lacking

- Public understanding and other law enforcement officials on Diversion are still lacking.

- The role of the community is still minimal, especially from the community who are victims. 
- Cooperation with other agencies related to the implementation of Diversion has not been going well.

Solution:

- Conduct separate meetings (caucuses) to unify ideas between the victim and the child in conflict with the law so that an agreement is reached

- Optimizing facilities and infrastructure

- Establishing Intensive Communication with Other Law Enforcement Officials

- Organizing Socialization about Diversion Among the Community

- Make an Agreement on Supervision of the Implementation of the Diversion Agreement Results

\subsection{Suggestion}

a. In carrying out their duties, both investigating, prosecuting, examining and determining case decisions at court proceedings, law enforcement officials should prioritize the implementation of diversion as an alternative to imprisonment.

b. To related parties (Law Enforcement, KPAI, etc.). It is necessary to do massive outreach regarding diversion to the public.

c. To the government, it is necessary to provide diversified facilities and infrastructure in order to guarantee protection for children.

d. Parents should be able to understand the case settlement system against children who are in conflict with the law

\section{Bibliography}

\section{Џournal and internet}

Aristo, Muhammad Adiel. \& Ma'ruf, Umar. "Criminal Law Policy against Actor of Criminal Performance Persecution". In Jurnal Daulat Hukum Volume 3 Issue 1, March 2020 ISSN: 2614-560X

Srinitri, Ni Made., \& Ma'ruf, Umar. "Progressivity Of Criminal Handling Fraud And Disease By The Directorate Of The General Criminal Researcher Of Central Java Regional Police (POLDA)". in Jurnal Daulat Hukum Volume 3 Issue 1, March 2020 ISSN: 2614-560X

Priyadi, Socialization \& Roadmap for the Implementation of Law no. 11/2012, retrieved from http://jabar.kemenkumham.go.id/ accessed on 2 May 2020 at 11.24 WIB

\section{Books}

Nashriana. (2011). Perlindungan Hukum Pidana Bagi Anak Di Indonesia, Jakarta: Raja Grafindo Persada.

Anggara., Napitulu, Ersmus A.T., \& Hernowo, Alex Argo. (2016). Studi Implementasi Penanganan Anak di Pengadilan Berdasarkan UU SPPA, Jakarta. 
Wahyudi, Setya. (2011) Implementasi Ide Diversi dalam Pembaruan Sistem Peradilan Pidana Anak di Indonesia, Yogayakarta: Genta Publishing.

United Nations Standard Minimum Rules for the Administration to the Administrations of Juvenile Justice ("The Beijing Rules"). Adopted by General Assembly Resolution 40/33 of 29 November 1985, Human Right A Compilation of International Instrumens Volume I (First Part) Universal instrumens, United Nations, New York, 1993.

Sunggono, Bambang. (1996). Metode Penelitian Hukum, Jakarta: Rajawali Pers.

Matthew , B. Miles., and Huberman, A. Michael. (1992). Analisa Data Kualitatif. Jakarta: UI Press.

Arief, Badra Nawawi. (2001). Masalah Penegakan Hukum dan Kebijakan Penanggulangan Kejahatan, Bandung: Citra Aditya Bakti.

Djamil MN. (2013) Anak Bukan untuk Dihukum, Sinar Grafika (cetakan kedua),

Kaligis, OC. (2006). Pelindungan Hukum Atas Hak Asasi Tersangka, Terdakwa, dan Terpidana, Jakarta: Alumni. 